\title{
Diethylene Triamine Pentaacetic Acid Clearance
}

National Cancer Institute

\section{Source}

National Cancer Institute. Diethylene Triamine Pentaacetic Acid Clearance. NCI

Thesaurus. Code C100441.

A measurement of the volume of serum or plasma that would be cleared of

Diethylenetriamine pentaacetate (DTPA) through its excretion for a specified unit of time. 